\title{
European Insider Trading Theory Revisited: The Limits of the Parity-of-Information Theory and the Application of the Property Rights in Information Theory to Activist Investment Strategies
}

\author{
by
}

Ana TAleska*

Parity-of-information is purported to be the single overarching policy rationale for the European Union $(E U)$ regulation on insider trading. This is because securities trading on the basis of informational advantages is generally probibited under EU rules, as is tipping (and issuers' selective disclosure) of material, non-public information. Yet, EU regulations allow market actors, including investment professionals and analysts, that have discovered valuable information-and thereby, have an informational advantage vis-à-vis their trading counterpartiesto trade on this information. Relatedly, issuers of financial instruments, takeover bidders and merging parties can share information with a selected group of investors prior to public announcement of the transaction (market sounding), whereas firms can delay public disclosure of inside information and prevent all other market participants from trading on this information.

I argue that these exceptions from the parity-of-information theory are-from a doctrinal standpoint- best explained as property rights in information of market actors that have developed new proprietary information with respect to European listed securities. This article, therefore, aims at providing a property rights account of the exceptions to the parity-of-information theory and it illustrates the trade-offs between the parity-of-information and the property rights in information theories underlying European insider trading rules. By extension, I analyze the specific case of activist campaigns as inside information and argue that it would be consistent with the property rights approach to allow activist investors to share their investment and trading strategies with other market participants that further their activist agenda.

Keywords: Insider Trading, Active Investment Strategies, Hedge Fund Activism, Property Rights in Information

* Ph.D. Candidate \& Research Fellow, Ghent University.

Acknowledgement: I would like to thank Hans De Wulf, James D. Cox, the participants to the 21st Annual Law and Business Conference at Vanderbilt Law School (May, 2019) and an anonymous reviewer of the European Company and Financial Law Review, for their valuable comments to an earlier draft of this paper. All errors are my own. Comments are welcome at ana.taleska@ugent.be. 


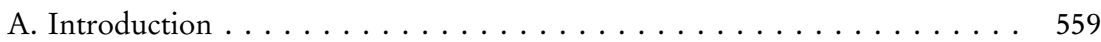

B. The Parity-of-Information Theory and European Insider Trading Rules . . . 563

I. European Insider Trading Rules in a Nutshell . . . . . . . . . . . . . 563

II. Parity-of-Information and the European Insider Trading Theory . . . . 567

C. Property Rights in Information and European Insider Trading Rules . . . . . 571

I. Analysts' Research and Recommendations . . . . . . . . . . . . . . 572

II. Trading on Proprietary Investment and Trading Strategies . . . . . . . 574

III. Issuers' Right to Delay Public Disclosure of Inside Information . . . . . . 575

IV. Market Sounding / Wall-Crossing . . . . . . . . . . . . . . . . . 578

D. Investor Activism under European Insider Trading Rules _ . . . . . . . . 580

I. Activist Campaigns as Inside Information . . . . . . . . . . . . . . 581

II. Trading on Active Investment Strategies under the EU Market Abuse Regulation........................... 589

E. Applying the Property Rights in Information Theory to Hedge Fund Activism: Extensions . . . . . . . . . . . . . . . . . . . . . 590

I. The Case for Allowing Selective Disclosure of an Activist Strategy . . . 590

II. The Case for Allowing Tippees to Trade on an Activist Strategy . . . . . . 594

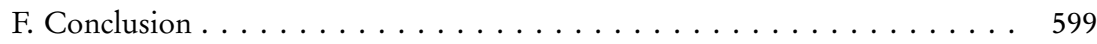

\section{A. Introduction}

There are a few areas in the American corporate and securities law scholarship that have been such a fruitful theorizing ground as insider trading. To better illustrate this point, I first take the example of nonpublic price-sensitive information originating from a publicly traded firm. Under the parity-of-information theory, this information is allocated to the market at large and the firm has to promptly disclose it to the public. ${ }^{1}$ Conversely, under the property rights in information theory, the firm has a property right in the information and can exploit the information according to its best interests i.e. by transacting on the information without disclosure to the trading counterparties or by sharing it with insiders and/or third parties (suppliers, contractors) and authorizing them

1 See generally Frank H. Easterbrook, "Insider Trading, Secret Agents, Evidentiary Privileges, and the Production of Information”, Supreme Court Review, 1981, 309, 324-330; Johnatan R. Macey, "From Fairness to Contract: The New Direction of the Rules Against Insider Trading”, Hofstra Law Review 13 (1984), 9, 13-24; Roberta S. Karmel, "Outside Trading on Confidential Information - A Breach in Search of a Duty", Cardozo Law Review 20 (1998), 83, 103-107. 
to trade on this information. ${ }^{2}$ Under a "negative" property rights in information theory, insiders are denied the right to trade on nonpublic price-sensitive information so that market analysts can compete in acquiring this information and subsequently, profit from trading on it. ${ }^{3}$

When socially valuable material information originates from market participants other than the firm (outsiders), they have to disclose this information to the market or abstain from trading under the parity-of-information theory (the "disclose-or-abstain" rule). Alternatively, under the misappropriation theory they can trade on the information without disclosing it to the market, unless a fiduciary duty or a duty of trust and confidence to the source of the information (which can either be the issuing firm or another securities market participant) is breached. ${ }^{4}$ Under the property rights in information theory, outsiders can keep the information confidential, trade or share this information or authorize third parties to use it. Finally, under a proposal to internalize outsider trading, outsiders can trade on the basis of information they have created only upon obtaining prior consent from the firm. ${ }^{5}$

Each of these theories is a function of the policy objectives it aims to achieve. The parity-of-information theory is a fairness-based doctrine centered on the idea that trading on informational advantages shall undermine investor confidence and the integrity of capital markets. ${ }^{6}$ The property rights in information theory allocates property rights to information-owners so that their incentive to engage in socially valuable research of market securities and discovery of new information is preserved. ' Under a contractual -as opposed to regulatoryapproach to allocating the use of nonpublic price-sensitive information, firms would vest property rights in newly created information to insiders as a form of compensation for their services. ${ }^{8}$ A "negative" property rights in informa-

2 See generally Richard J. Morgan, "Insider Trading and the Infringements of Property Rights”, Ohio State Law Journal 48 (1987), 79; Anthony T. Kronman, "Mistake, Disclosure, Information, and the Law of Contracts”, Journal of Legal Studies 7 (1978), 1, 15; Macey (fn. 1), 24-26; Karmel (fn. 1), 112-113.

3 See generally Zohar Goshen/Gideon Parchomovsky, "On Insider Trading, Markets, and “Negative” Property Rights in Information”, Virginial Law Review 87 (2001), 1229.

4 United States v. O'Hagan 521 U.S., 1997, 642, 654-657.

5 See generally Ian Ayres/Stephen Choi, "Internalizing Outsider Trading”, Michigan Law Review 101 (2002), 313.

6 See sources cited supra (fn. 1).

7 See sources cited supra (fn. 2).

8 See generally Dennis W. Carlton/Daniel R. Fischel, “The Regulation of Insider Trading”, Stanford Law Review 35 (1982), 857, 894-895 (arguing that insider trading should be a matter of private contracting between firms and managers as firms have incentives to "allocate property rights in information to the highest-valuing user"); Henry Manne, Insider Trading and the Stock Market, 1966; Naveen Khanna/Steve L Slezak/Michael Bradley, 
tion encourages competition between market analysts for the purpose of achieving efficient information markets ${ }^{9}$, whereas the objective of the internalization approach to outsider trading is to deter socially wasteful (duplicative) research and to reassign outsiders' informational rights to the firm so that outsiders can trade on informational advantages they have created only if the firm agrees ex ante to it. ${ }^{10}$

This breadth of doctrinal analysis of insider trading liability is not reflected in the European scholarship on insider trading. In fact, parity-of-information is the only theoretical approach put forward to explain the EU insider trading policy. ${ }^{11}$ However, even though the three general prohibitions under the EU insider trading rules -the insider trading ban, the tipping ban and the selective disclosure ban $-{ }^{12}$ are doctrinally rooted in the parity-of-information theory, the EU insider trading policy -in an exception to the parity-of-information theoryalso rewards the creation of socially valuable information by market professionals and issuers and allocates to these market actors the right to trade on and/or selectively share the inside information they have created, without disclosing it to the market. For example, analysts can trade and/or disclose to clients their reports and recommendations, without violating the insider trading

"Insider Trading, Outside Search and Resource Allocation: Why Firms and Society may Disagree on Insider Trading Restrictions" The Review of Financial Studies 7 (1994), 575 (contesting Carlton-and-Fischel's argument by arguing that insider trading by managers reduces the incentives of outsiders to search for valuable information and as a result, the quality of outside information is also reduced; thus, the costs from insider trading differ between firms and society and their respective incentives for regulating insider trading are also different).

9 Gohen/Parchomovsky (fn. 3), 1262-1265.

10 Ayres/Choi (fn. 5), 359-360.

11 See Marco Ventoruzzo, "Comparing Insider Trading in the United States and in the European Union: History and Recent Developments”, European Company and Financial Law Review 2006, 554; Edward Greene/Olivia Schmid, "Duty Free Insider Trading”, Columbia Business Law Review, 2013, 369, 372; Lars Klöhn, “The European Insider Trading Regulation after Spector Photo Group”, European Company and Financial Law Review, 2010, 347; Niamb Moloney, EU Securities and Financial Markets Regulation, 2014, 701 (distinguishing between the relationship-based and the marketbased theory of insider trading regulation, and arguing that the EU regulation is influenced by the latter theory (with macro-focus), whereas approaching insider trading as a mechanism for allocating property rights falls within the former theory (with microfocus)); Guido Ferrarini, European Market Abuse Directive, Common Market Law Review 41 (2004) 711, 714 (arguing that the investor confidence-argument for regulating insider trading under the 2003 Market Abuse Directive "might be of some value if it made reference to transaction costs faced by investors" and more generally, suggesting that the property rights in information can be an alternative rationale for regulating insider trading).

12 See infra section B.I. 
and/or tipping ban, respectively. ${ }^{13}$ Similarly, active investors can develop investment strategies and trade on this basis without violating the insider trading ban $^{14}$. Further, European firms can delay the disclosure of material confidential information provided there is a legitimate reason for the non-disclosure (e.g. when a disclosure would prejudice the market value of the information) without violating the selective disclosure ban. ${ }^{15}$ Lastly, takeover bidders and merging firms can conduct pre-marketing activities and wall-cross shareholders prior to public announcement of the transaction, without violating the tipping ban. ${ }^{16}$ In each of these cases, the EU legislator essentially protects the confidential nature of the information that different market actors have produced so that they can trade and/or share that information (depending on the specific rule) in a manner that preserves their incentives to create new information in the future.

Against this background, the goal of this Article is to challenge the generally accepted notion of the parity-of-information theory as a "grand unifying theory" of EU insider trading regulation. ${ }^{17} \mathrm{I}$ argue that the trading rights as well as the right to (selectively) disclose informational advantages granted under the EU Regulation on Market Abuse ${ }^{18}$ (the Market Abuse Regulation) to market participants that develop new information about listed securities, are best viewed as property rights in information and that the currently applicable EU insider trading rules are inherently reflective of the trade-offs between the parity-of-information and the property rights in information theories.

Subsequently, I take the case of activist investors' interventions at target firms and argue that under the Market Abuse Regulation, activist hedge fund strategies would likely qualify as price-sensitive (nonpublic) information created by hedge fund managers. Activists at European listed firms can trade on this proprietary information but cannot share it with other hedge funds or institutional investors. I argue, however, that allowing hedge funds to share their investment strategy with other investors (given that alliances between hedge funds, and hedge funds and institutional investors more generally, can be critical for the success of activist campaigns) would be consistent with the property rights approach. By extension, I argue that allowing hedge funds' tippees to trade on the information disclosed by the lead hedge fund (i.e. the fund that has devel-

13 See infra section C.I.

14 See infra section C.II.

15 See infra section C.III.

16 See infra section C.IV.

17 See infra section B.II.

18 Regulation (EU) No 596/2014 of the European Parliament and of the Council of 16 April 2014 on market abuse (market abuse regulation) and repealing Directive 2003/ 6/EC of the European Parliament and of the Council and Commission Directives 2003/ 124/EC, 2003/125/EC and 2004/72/EC. 
oped and initiated the activist campaign) is also consistent with the property rights in information theory, to the extent the information-owner (lead hedge fund) consents to such trading and the (price-sensitive, non-public) information about the activist campaign is kept confidential.

This Article proceeds as follows. Section B outlines the general insider trading prohibitions under EU law and sets out the theoretical positing of these restrictions in the parity-of information theory. Section $C$ explains how the property rights in information theory addresses the deficiency in the explanatory power of the parity-of-information theory and applies a property rightsanalysis to elaborate on the rationale behind specific rules set forth in the Market Abuse Regulation that deviate from the parity-of-information approach. Section D focuses on investor activism and analyzes -from an insider trading perspective- activist campaigns and securities trades on the basis of a prior decision to launch an activist intervention. Finally, section $\mathrm{E}$ uses the property rights in information theory to evaluate the case for giving hedge funds the right to selectively share (tip) other institutional investors about an upcoming activist campaign and for allowing these tippees to trade on this information.

\section{B. The Parity-of-Information Theory and European Insider Trading Rules}

European insider trading law has three general rules at its core: the insider trading ban, the tipping ban and the selective disclosure ban. Their main purpose is to level the playing field between market participants by restricting the use of informational advantages when trading on securities markets. In theoretical terms, these restrictions are based on the parity-of-information theory in securities regulation. In this chapter, I firstly set out the key elements of these three restrictions under the Market Abuse Regulation (infra I) and thereafter, explain their theoretical positing based on informational parity (infra II).

\section{European Insider Trading Rules in a Nutshell}

Consistent with the Continental European legal tradition, the substantive rules on trading on inside information in Europe have been set out in one single legislative instrument - a regulation adopted by the EU legislator directly applicable ${ }^{19}$ in all national (EU) jurisdictions as of July 2016. ${ }^{20}$ The European legal frame-

19 Paul Craig/Grainne de Burca, EU Law: Text, Cases and Materials, 6th ed., 2015, p. 184 (discussing the EU doctrine of direct effect).

20 See Regulation (EU) 596/2014 (fn. 18). Regulation (EU) 596/2014 was preceded by the Market Abuse Directive 2003/6/EC of the European Parliament and of the Council of 
work on insider trading is further complemented - albeit only with a limited number of opinions ${ }^{21}$ - by the jurisprudence of the European Court of Justice, the judicial body of the EU deciding on disputes and giving interpretative guidance in connection with the application of EU law. In addition to aligning the substantive rules on insider trading, EU legislators have also adopted rules on administrative and criminal sanctions for insider trading violations, requiring minimum harmonization across $\mathrm{EU}$ jurisdictions while leaving the possibility to the individual Member States to adopt a more severe administrative and criminal penalties for market actors engaging in insider trading. ${ }^{22}$ The three key restrictions for securities traders forming the basis of and reflecting the parity-of-information theory under the EU insider trading regulation are the insider trading ban, the tipping ban and the selective disclosure ban.

The Insider Trading Ban. Securities trading on the basis of material, non-public information is generally prohibited under EU rules. Qualifying as an insider is solely by virtue of being in possession of an inside information, regardless of the capacity in which that person acquired the information (e.g. as a fiduciary of a corporate entity or as a result of a relationship of trust and confidence with the source of the information). ${ }^{23}$ In other words, the EU definition of the term "insider" is centered on the information that the person possesses, and not on how that person has come to possess such information (e.g. through a breach

28 January 2003 on insider dealing and market manipulation (market abuse)). Regulation (EU) 596/2014 foresees the adoption of a number of implementing acts whose purpose is to bring clarity and provide more detail in the implementation of important concepts set forth therein; for a full list of all implementing and delegated acts for Regulation (EU) 596/2014 see: <https://ec.europa.eu/info/sites/info/files/business_economy_ euro/banking_and_ finance/documents/mar-level-2-measures-full_en.pdf> (last accessed on 25 November 2019); for helpful overview of the reforms implemented in Regulation (EU) 596/2014 in comparison with Directive 2003/6/EC, see generally, Mathias Siems/Matthijs Nelemans, "The Reform of the EU Market Abuse Law: Revolution or Evolution", Maastricht Journal of European and Comparative Law 19 (2012), 195; Carmine di Noia, "Pending Issues in the Review of the European Market Abuse Rules", ECMI Policy Brief No. 19, 2012 <https://papers.ssrn.com/sol3/papers.cfm?abstract_ $\mathrm{id}=2028918>$ (last accessed on 24 September 2019).

21 See generally ECJ, 10 May 2007, Ipourgos Ikonomikon, Proistamenos DOI Amfissas v Georgakis, C-391/04, ECLI:EU:C:2007:272; ECJ, 22 November 2005, Knug Grøngaard and Bang, C-384/02, ECLI:EU:C:2005:708; ECJ, 23 December 2009, Spector Photo Group NV, C-45/08, ECLI:EU:C:2009:806; ECJ, 28 June 2012, Markus Geltl v. Daimler, C-19/11, ECLI:EU:C:2012:397.

22 Directive 2014/57/EU of the European Parliament and of the Council of 16 April 2014 on criminal sanctions for market abuse (market abuse directive).

23 Chiarella v United States 445 U. S., 1980, 222, 231; Dirks v SEC 463 U. S., 1983, 646, 659 (setting out the fiduciary-duty requirement for imposing insider trading liability under U.S. law). 
of a duty)..$^{24}$ The only backstop to the application of this insider trading proscription is that the person acted with scienter, i.e. s/he knew or ought to have known that it is in possession of inside information when executing the securities transaction to which the inside information pertains. ${ }^{25}$ From a comparative perspective, this broad prescription of the scope of persons qualifying as insiders casts the widest possible liability net for insider trading violations.

The Tipping Ban. Sharing of inside information is another restriction under EU rules, constituting a violation of insider trading rules that is separate and may come in addition to the insider trading ban. Any person in possession of inside information qualifies as a tipper, if it discloses inside information to any other person. ${ }^{26}$ The tipper need not personally benefit from sharing the inside information nor be in a specific relationship with the tippee for a tipper-tippee liability to arise under EU law (i.e. no derivative liability). ${ }^{27} \mathrm{~A}$ remote tippee may also qualify as insider as long as knowledge of possession of a nonpublic, price-sensitive information can be shown. ${ }^{28}$

The Market Abuse Regulation sets out limited circumstances, however, when disclosure of inside information is not unlawful, such as if disclosure is made "in the normal exercise of an employment, a profession or duties". ${ }^{29}$ In the practice of the European Court of Justice, this rule has only been tested in the context of an employee-representative on the board of a listed firm sharing sensitive information with its constituency i.e. with representatives of the employee union about a potential merger involving the firm. ${ }^{30}$

Aside from the context of disclosures between different actors within the issuer's organization, sharing of inside information is not unlawful if market participants engage in market sounding and approach investors in relation to a prospective offering of financial securities. Additionally, takeover bidders and merging firms may also wall-cross investors to determine their interest in participating in the transaction (takeover bid or merger, respectively). ${ }^{31} \mathrm{How}-$ ever, for market sounding practices to qualify as lawful sharing of otherwise non-public, price-sensitive information, the disclosing market participant

24 Greene/ Schmid (fn. 11), 377.

25 Art. 8(3) Regulation (EU) 596/2014.

26 Art. 10 Regulation (EU) 596/2014.

27 Dirks (fn. 23) (setting out the concept of derivative liability in tipping cases as developed by the U.S. Supreme Court).

28 Art. 8(3) Regulation (EU) 596/2014.

29 Art. 10(1) Regulation (EU) 596/2014.

30 Grøngaard and Bang (fn. 21).

31 Art. 11(2) Regulation (EU) 596/2014. For a more detailed discussion of the marketsounding rule under Regulation (EU) 596/2014, see infra section C.IV. 
should comply with specific record-keeping requirements set out in the Market Abuse Regulation, further elaborated in Section E.2 infra. ${ }^{32}$

The Selective Disclosure Ban. Under EU rules, issuers have an affirmative obligation to promptly and continuously disclose to the public any inside information that directly concerns them. ${ }^{33}$ The rule essentially works to increase the flow of material information to capital markets so that securities prices incorporate all publicly available information and thereby, increase stock market efficiency. ${ }^{34}$ Immediate public disclosure of material information also restricts issuer's incentive and ability to selectively share inside information to a group of privileged market professionals and it effectively pre-empts insider trading by corporate officials. Such a sweeping disclosure obligation, however, may easily trigger issuer liability for an improper disclosure or non-disclosure, which under EU rules may lead to a fine of $€ 2$ million or $2 \%$ of its total annual turnover. ${ }^{35}$

In complying with their continuous disclosure obligations, European issuers have to make several determinations with respect to information they may have to disclose. Firstly, they need to distinguish between information of direct and indirect concern to the issuer, as only the former falls within the scope of the continuous disclosure obligation. Under the 2007 guidance of the Committee of European Securities Regulators, information produced by the issuer itself would likely be of direct concern as opposed to information produced outside the issuer by, for example, investment analysts, active investors or governmental agencies, which is deemed to concern the issuer only indirectly and as such, need not be publicly disclosed by the issuer. ${ }^{36}$ Secondly, the selective

32 Art. 11(4), 11(5) Regulation (EU) 596/2014. For a more detailed discussion on the record-keeping rules in the context of market sounding, see infra section E.II.

33 Issuers may - under certain conditions - delay public disclosure of inside information. For further discussion on the issuer's right to delay public disclosure, see infra C.III.

34 See generally Ronald J. Gilson/Reinier H. Kraakman, "The Mechanisms of Market Efficiency", Virginia Law Review 70 (1984), 549 (explaining how efficiency of the securities prices is determined by the joint operation of by capital market mechanisms and information market).

35 Art. 30(2)(j)(ii) Regulation (EU) 596/2014.

36 The Committee of European Securities Regulators, Market Abuse Directive, Level 3 Second Set of CESR Guidance and Information on the Common Operation of the Directive to the Market, 2007, 7-8 [hereinafter CESR Guidance] <https://www.esma. europa.eu/document/market-abuse-directive-level-3-\%E2\% 80\%93-second-set-cesrguidance-and-information-common-operation $>$ (last accessed on 6 November 2019). The Committee of European Securities Regulators was an independent network of supervisory authorities in the European Union. As of 1 January 2011, the European Securities Markets Authority was set up as a legal successor of the Committee of European Securities Regulators, see Art. 76, Regulation (EU) No 1095/2010. 
disclosure ban requires issuers to determine whether the information they have developed qualifies as inside information under EU rules. In many instances this may be a challenging task for issuers as they have to decide whether the information is precise, price-sensitive, and non-public, and as a result, has to be publicly disclosed. ${ }^{37}$

From a comparative perspective, and with the goal of narrowing the scope of inappropriate and overly broad liability for issuers in connection with their disclosure duties, the U.S. Regulation Fair Disclosure (the Regulation FD), for example, restricts selective disclosure by asking issuers to fully disclose material information (only) to securities market professionals and securities holders. Further, this obligation applies to communications by issuer's senior officials and employees regularly communicating with investors and securities market professionals. ${ }^{38}$ Regulation FD is thus more issuer-friendly compared to the Market Abuse Regulation in two respects: first, it limits the range of communications wherefrom liability may arise i.e. to communications with market professionals and investors, and second, it narrows down the officers within the issuer's organization whose communications should be scrutinized for (inadvertent) sharing of inside information.

As these reservations are not envisaged under the Market Abuse Regulation, any and all communications with parties outside the issuer (including ordinary business communications) by any employee may result in liability for European issuers, if material nonpublic information would be disclosed. Farreaching disclosure obligations when combined with severe pecuniary penalties may deter European securities issuers from engaging in communications where material nonpublic information may be inadvertently disclosed, affecting in particular analysts and investment professionals which ordinarily meet with corporate officials in order to get acquainted with different aspects of issuer's operations relevant for their investment and trading decisions as well as client recommendations.

\section{Parity-of-Information and the European Insider Trading Theory}

The parity-of-information theory is premised on the notion of informational equality between capital market actors i.e. knowledgeable parties are disallowed from trading on informational asymmetries, and in that manner, from

37 Dirks (fn. 23) (arguing that corporate officers may not always be aware that they have disclosed inside information). For a more detailed discussion of this three-part test on the definition of insider information, see infra section D.I.

3817 C.F.R $₫ 243,2015,100-103$. 
taking advantage of uninformed parties in the context of securities trading. The central idea behind this fairness-based doctrine is that informational disparities between securities market participants undermine investor confidence and the integrity of financial markets ${ }^{39}$, and thereby, adversely affect the development (and liquidity) of capital markets. In practical terms, the parity-of-information theory is implemented in securities regulations through the "disclose-or-abstain" rule i.e. insiders have the choice to either disclose the inside information before trading, or refrain from trading. ${ }^{40}$ Given that insiders have fiduciary and/or confidentiality obligations preventing them from publicly disclosing price-sensitive corporate information, the disclose-or-abstain rule typically turns into a duty to abstain from trading.

There are two degrees of informational parity that legislators may exact from market participants, including issuers. If a broad interpretation of the parityof-information theory is adopted, all market actors should have equal information prior to trading (informational equality). Yet, requiring that every investor has the same set of information may be an unattainable regulatory objective, unsuited to the realities of today's complex securities markets where fundamental analysis of companies and investment strategies are mainly a function of skill, time and resources, even if the same set of underlying information is supplied to all trading parties. ${ }^{41} \mathrm{~A}$ narrow version of the parity-of-information theory, as adhered to in the fairness-based regulatory regimes, however, is based on equal access to information. Under this approach, investors need not possess the exact same information at the time of trading as long as they have access to it. ${ }^{42}$

39 See generally Kim Lane Scheppele “It's Just Not Rights: The Ethics of Insider Trading”, Law and Contemporary Problems 56 (1993), 124 (analyzing the fairness-based ratio of insider trading regulation from an ethical perspective); Janet Austin, "What Exactly is Market Integrity? An Analysis of on One of the Core Objectives of Securities Regulation”, William \& Mary Business Law Review 8 (2017), 215 (trying to supply meaning to the notions of market integrity and fairness in the context of securities regulation and insider trading); Ferrarini (fn. 11), 714 (arguing -in the context of the 2003 Market Abuse Directive- that "the violation of market integrity needs further specification as does the reference to investor confidence").

40 SEC v. Texas Gulf Sulphur Co. 401 F.2d 1968, 833, 848 (providing that "anyone in possession of material inside information must either disclose it to the investing public, or, if he is disabled from disclosing it in order to protect a corporate confidence, or he chooses not to do so, must abstain from trading in or recommending the securities concerned while such inside information remains undisclosed").

41 See generally O'Hagan (fn. 4) (the U.S. Supreme Court in O'Hagan argued that “informational disparities are inevitable in the securities markets").

42 The equal-access standard, however, is not self-defining and economic theoreticians have criticized the parity-of-information theory as vague, overbroad and devoid of content; see Easterbrook (fn. 1), 324-330 (arguing that the fairness-doctrine could either 
In the EU, the Market Abuse Regulation provides that it aims to restrict " $u n$ fair advantage being obtained from inside information to the detriment of third parties who are unaware of such information" ${ }^{43}$ resulting in "undermining of the integrity of financial markets and investor confidence", which [investor confidence] is based "on the assurance that investors will be placed on an equal footing and protected from the misuse of inside information" ${ }^{44}$. This wording suggests that informational equality is not a per se requirement for a lawful trading on the European securities markets and that trading on informational asymmetry is permitted as long as it is obtained in an unfair manner. The Market Abuse Regulation, however, stops short of setting out a general principle or a theoretical foundation to govern the distinction between fair and unfair informational advantages.

An obvious example of a fair informational advantage would be the value-discovery function of market professionals, given the resource-extensive financial analytical work that analysts and investment managers put in place for the development of socially valuable information and the efficiency in securities' prices resulting from their trading activity on the basis of the information they create. ${ }^{45}$ One approach for policy-makers to encourage the production of socially valuable information by market professionals, therefore, is to adopt regulations that allow outsiders to trade on informational advantages they acquire as a result of their diligence and resources as long as their (structural) advantages can be lawfully overcome by other market participants ${ }^{46}$.

mean (i) equality of information, (ii) right to obtain identical returns, (iii) ability to trade at the right price or (iv) demanding that no wealth transfers take place).

43 Rec. (23), Regulation (EU) 596/2014.

44 Rec. (24), Regulation (EU) 596/2014.

45 See generally Sanford J. Grossman/Joseph E Stiglitz, “On Impossibility of Informationally Efficient Markets”, American Economic Review 70 (1980) 393, 393 (arguing that the efficiency of the securities prices is a function of the number of informed market participants and that the information that informed market participants possess is only to a certain extent reflected in securities prices. As a result, market participants engaging in costly research and analysis of securities are rewarded by trading on the information they have acquired); see also generally Jeffrey N Gordon/Lewis A Kornhauser, "Efficient Markets, Costly Information and Securities Research", New York University Law Review 70 (1985) 761, 830-831 (arguing that capital markets are only "relatively" efficient, justifying the search for undervalued securities by sophisticated investors).

46 Victor Brudney, "Insiders, Outsiders, and Informational Advantages under the Federal Securities Laws”, Harvard Law Review 93 (1979) 322, 355 (arguing that one way to distinguish between informational advantages that can be used vis-à-vis trading counterparties is whether the informational advantage can be lawfully overcome by market participants, regardless of diligence or resources). 
The Market Abuse Regulation comes close to this approach, but not quite. Namely, under the Market Abuse Regulation, market professionals can conduct research and trade on the information they develop as long as their research is based on publicly available data. Yet, even though in many instances publicly available information is information that can be lawfully obtained, these two concepts are not equivalent, at least as far as the current operation of capital markets is concerned. For example, information may be lawfully accessible immediately upon its publication, but it may not immediately qualify as publicly accessible ${ }^{47}$ i.e. a time-lag may be necessary to allow investors to acquaint themselves and "digest" the disclosed information before it is reflected in securities prices.

Further, for the equal access-principle to be synonymous with a regulatory approach allowing trades based exclusively on publicly available information, a workable and comprehensive definition of the term "public information" needs to exist. This is presently not the case under EU law. Even though there are technical standards that European issuers need to observe when publicly disclosing inside information ${ }^{48}$, no guidance exists for securities traders in terms of when an information is deemed publicly available and can be used for trading purposes. To complicate things even further, the European securities regulators have adopted a position that they may assign a different meaning to the term "public information" depending on whether this term is used in the context of a securities transaction or in the context of issuer's continuous disclosure obligation. Consequently, information improperly disclosed by the issuer may be deemed public, when used for trading purposes by individual market participants. ${ }^{49}$ And while there is a sound public policy rationale for setting a stricter interpretation of the "public information" definition in the context of issuers" public disclosure obligations, more clarity is needed of this key concept in the European insider trading regulation in the context of securities trading. ${ }^{50}$

47 Financial Conduct Authority, Handbook on Rules and Guidance, MAR 1.2.12E, <https://www.handbook.fca.org.uk/handbook/MAR/1/2.html?date=2016-03-07> (last accessed on 24 September 2019) (the British Financial Services Authority uses the general availability of the information as a disclosure-standard for public information).

48 Commission Implementing Regulation (EU) 2016/1055 of 29 June 2016 laying down implementing technical standards with regard to the technical means for appropriate public disclosure of inside information and for delaying the public disclosure of inside information in accordance with Art. 2 of Regulation (EU) No 596/2014.

49 CESR Guidance (fn. 36), 5; but, see Kraakman/Gilson (fn. 34), 572 (arguing that analysts and portfolio managers control a critical volume of trading activity and through their informed trading, securities prices are adjusted to reflect the true value of firm's securities. As a result, they argue that information that is accessible to a substantive portion of market professionals, should be deemed publicly disclosed).

50 See infra section D.I.1.a, for a more detailed discussion on this issue. 


\section{Property Rights in Information and European Insider Trading Rules}

As already discussed in the foregoing section $\mathrm{B}$, market professionals perform a valuable function on securities markets. Portfolio managers and analysts, however, would have little incentive to engage in a resource-intensive analysis of market securities without being able to profit from their informational advantages by engaging in informed trading.

To take the example of activist investors, hedge fund managers have not only a valuable price- and information -discovery function on the securities markets, but they also play an important corporate governance role by intervening at underperforming and/or undervalued companies and reducing shareholdermanager agency costs. ${ }^{51}$ Yet, an activist campaign that includes a proxy fight has been estimated to cost $\$ 10.71$ million - an expense no shareholder would be willing to incur if it was not allowed to trade in target's securities prior to publicly announcing its intervention. ${ }^{52}$

From this perspective, it is only rational that policymakers grant market professionals property rights in the information they produce. ${ }^{53}$ Holding a property right in information would allow the information-owner to either trade on the information without disclosing it to the market or to prevent third parties from trading on it. ${ }^{54}$ If informed parties that have developed information through diligent research of firms and securities are not assigned property rights and have to disclose the informational advantage prior to trading on the market, they would have no incentive to engage in the production of new information in the future. On the other hand, the incentives of market actors that have not searched for but have been simply conferred valuable information by another knowledgeable party, would be unchanged even if disclosure before trading is legally mandated. ${ }^{5}$

51 See generally Lucian A. Bebchuk/Alon Brav/Wei Jiang, "The Long-Term Effects of Hedge Fund Activism”, Columbia Law Review 115 (2015), 1085.

52 See Nickolay Gantchev, "The Cost of Shareholder Activism: Evidence from a Sequential Decision Model”, Journal of Financial Economics 107 (2013), 610, 611.

53 See generally Ayres/Choi (fn. 5) (arguing that rights to valuable information produced by market professionals should be allocated to the firm itself, in order to deter socially suboptimal securities research).

54 Stephen M. Bainbridge, "Insider Trading Regulation: The Path Dependent Choice between Property Rights and Securities Fraud", Southern Methodist University Law Review 52 (1999) 1589, 1607; Stephen M. Bainbridge, "Regulating Insider Trading in the Post-Fiduciary Era: Equal Access or Property Rights”, UCLA School Of law, LawEcon Research Paper No. 12-08, 2012, 20-32 <https://papers.ssrn.com/sol3/papers. cfm?abstract_id=2054814> (last accessed on 25 September 2019); Kronman (fn. 2), 15.

55 Kronman (fn. 2), 13-15 (distinguishing between information obtained by deliberate search and casually acquired information). 
Given that market egalitarianism is of little value if capital markets are inefficient, European policymakers have granted specific property rights to information-owners by allowing them - under specific circumstances - to trade and/or selectively share the information they have developed without disclosing it to the market. In this section C, I analyze the property rights in information allocated under the Market Abuse Regulation to analysts (infra I), market professionals developing proprietary investment and/or trading strategies (infra II), issuers (infra III) and market actors conducting market soundings (infra IV).

\section{Analysts' Research and Recommendations}

Analysts have a valuable function on securities markets. Using their resources, knowledge and skill, they collect and evaluate firm-specific information and develop reports and recommendations for further sale or disclosure to their clients, which subsequently adopt investment and trading decisions.

Under a property rights approach, analysts would have a property right in the information they develop as a product of their diligent financial analytical work and can either (selectively) share (i.e. disclose to their clients but not to the public) or trade on that information without publicly disclosing it. EU insider trading rules applicable to analysts are along these lines. Under the Market Abuse Regulation, analysts' research and recommendations do not constitute inside information and securities trades executed on this basis do not amount to insider trading. ${ }^{56}$ Analysts' property rights in their work-product, however, is not absolute as it vests only if analysts' research and recommendations are conducted on the basis of publicly available data. This requirement draws from the parity-of-information/equal-access, principle as it is intended to ensure that all market participants, including the most sophisticated market professionals such as securities analysts, cannot use inside information in their reports and recommendations.

The egalitarian function of this rule, however, is attenuated by the fact that information that can be obtained by analyzing or developing information that is generally available, also counts as public information. ${ }^{57}$ Thus, analysts may observe firm's operations and facilities, conduct interviews with corporate officers and/or employees, and on that basis develop reports and adopt recommendation with respect to firm's securities. As long as no inside information was disclosed in this process of collecting and evaluating information, analysts

56 Rec. (28) Regulation (EU) 596/2014.

57 MAR 1.2.12E, Financial Conduct Authority (fn. 47). 
are free to use their skill and expertise to create new, nonpublic information about the value of firm's securities and subsequently share and/or use them for trading purposes.

Analysts' research, however, that is based on nonpublic price-sensitive information may qualify as inside information under EU laws and trades executed on the basis of this information shall constitute insider trading. This is an important difference with the U.S. law and jurisprudence where under the U.S. Supreme Court opinion in Dirks, analysts are not prevented from using nonpublic information when researching firm's securities as this would undermine their incentive to diligently gather and analyze information and would adversely affect market efficiency in securities prices. ${ }^{58}$

The facts of Dirks are as follows. Dirks was an analyst covering the insurance industry and was tipped off by a former employee (Secrist) of an insurance firm (Equity Funding) that due to fraudulent corporate practices, the Equity Funding's assets were significantly overstated. After receiving the tip, Dirks visited Equity Funding and conducted interviews with employees, who confirmed the fraud allegations. Dirks tried to have his discovery publicly known, but the media outlets declined to published it. He did not trade himself on this information but shared this information with his clients and other investors, who traded on it and avoided significant loses once the fraud was uncovered. As a result, the share price started plummeting and subsequently, the state insurance authorities investigated and uncovered the fraud.

Dirks was charged by the SEC for breaching a fiduciary duty towards the shareholders of Equity Funding by tipping information about the fraud he discovered to third parties, who subsequently traded on this inside information. The case was ultimately brought before the U.S. Supreme Court, which developed a new theory for tipping cases, centered on a requirement that the tippee's liability is derivative of the tipper's liability and that the tipper is liable if $s$ /he obtains personal benefit for providing the tip. On the basis of this test, Dirks was found not to have breached a disclosure duty as the personal-benefit test was not satisfied i.e. Secrist and the other Equity Funding employees did not receive anything in return for disclosing the fraud to Dirks.

Under the Market Abuse Regulation, however, this case would turn out differently. The tip regarding the fraudulent practices of the firm that Dirks received from Equity Funding's (former) employees was an inside information at the time Dirks disclosed it to its clients and investors i.e. Dirk's research was made on the basis of inside information, which he unlawfully disclosed to other market participants in violation of the EU tipping ban. The obvious effect of the 
EU rules, therefore, is that analysts' incentives to engage in socially useful behavior such as investigating and uncovering fraud on the basis of a prior nonpublic material information (tip) are practically non-existent. ${ }^{59}$ If the analyst, either directly or through commissions from the trading activity of its clients cannot benefit from the information that the analyst develops (even if based on nonpublic material information), he would not pursue the research needed to verify the tip and as a result, the fraudulent activity would continue in operation at the expense of all investors in the securities markets.

Additionally, market professionals may also be in violation of EU insider trading rules if they trade or share information that is based on a publication or distribution of a report or analysis that has an effect on the formation of the prices of securities. For example, reports that are regularly published or expected by the market and that contribute to the securities' price-formation process may qualify as inside information, as well as the publication and/or distribution of views of a recognized market commentator or institution that informs the securities prices. ${ }^{60}$ In all these instances, market professionals are expected to ex ante know or predict the effect that the dissemination of their report or analysis shall have on price formation, and on that basis assess if trades executed before such publication would constitute insider trading.

In summary, analysts' right under the Market Abuse Regulation to use their work-product (reports, recommendations) for onward disclosure to clients and for trading purposes is reflective of the property rights in information approach. However, the rules governing the process of collection of information relevant for developing analysts' work product, are based on the equal-access principle. $^{61}$

\section{Trading on Proprietary Investment and Trading Strategies}

Analysts typically sell their reports and recommendations to investment professionals (sell-side analysts) or use them in-house (buy-side analysts). In each case, investment professionals and in particular, actively managed funds use analysts' research as a basis for adopting investment decisions and trading stra-

59 John C. Coffee Jr, "Introduction: Mapping the Future of Insider Trading Law: Of Boundaries, Gaps and Strategies”, Columbia Business Law Review 2 (2013), 290, 313 (arguing that Dirks would not have boarded the plane to visit Equity Funding and investigate the fraud if he could not subsequently share this information with his clients).

60 Rec. (28) Regulation (EU) 596/2014.

61 See supra section B.II, for a discussion on the difficulties in applying the equal-access principle and defining publicly available information in the context of the European insider trading policy. 
tegies. Under the Market Abuse Regulation, investment professionals and market actors generally developing proprietary investment plans and trading strategies can execute their own plans and strategies by entering into securities transactions, without disclosing them to the public. The right to trade on the informational advantage they have created is essentially a function of the property right that active investors, as information-owners, are granted under the Market Abuse Regulation.

These trading rights, however, come with two caveats. Firstly, they shall not apply where securities trades - while based on nonpublic price-sensitive information created by the informed party - are executed for an illegitimate reason. Rationally, the EU legislator would not shield from disclosure or allow trading on informational advantages that are used -and possibly created- for illegitimate purposes. Secondly, in developing their investment decisions and/or trading strategy, market actors may not use inside information i.e. they shall not be assigned property rights in the information they create if, in the process of collection and evaluation of information, they come across nonpublic material information and use this information to develop investment decisions or to execute trades. In this event, they must abstain from trading or their trades will constitute insider dealing.

\section{Issuers' Right to Delay Public Disclosure of Inside Information}

Value-relevant information with respect to issuers' securities does not originate from market professionals only. In fact, most of the information affecting issuer's assets and earning power emanates from the issuer itself. As a general rule, and consistent with the parity-of-information theory, European listed firms are required to promptly disclose inside information they have created to the public by observing specific technical standards ${ }^{62}$. In this manner, the European insider trading policy aims at ensuring the widest possible dissemination of inside information, which simultaneously works to restrict the chances of insiders trading on price-sensitive nonpublic information and selectively disclosing inside information to a privileged group of market participants (market analysts and/or hedge funds).

However, consistent with the property rights in information theory, European firms have the right -under specific circumstances- to keep proprietary information private by delaying public disclosure and to de facto prevent market participants from trading on it. More precisely, EU-based issuers may deviate from the selective disclosure ban and delay disclosure, provided (i) the issuer 
has legitimate interests that will be prejudiced by immediate public disclosure, (ii) the information remains confidential throughout the delay, and (iii) is not misleading the public. ${ }^{63}$ The legitimate interests of the issuer may include information relating to corporate restructurings, acquisitions by/of the issuer, the adoption of decisions or contracts that have to be approved internally by different board levels or invention of a new product that can be protected by intellectual property rights. ${ }^{64}$

In all these instances, the issuer essentially creates new proprietary information regarding its business that will lose value if disclosed before the issuer has had the opportunity to capitalize on it. In contrast, it may be difficult for an issuer to show a legitimate interest and justify a delay in public disclosure of information that the issuer did not develop through diligent research and extension of significant corporate resources and that will not lose value if immediately disclosed to the investing public, such as, for example, historic operating results typically disclosed in semi-annual and annual reports. This type of information has to be promptly disclosed in line with issuer's obligations for continuous disclosure of inside information as investors need transparency regarding issuer's operations and strategy in order to make prudent investment decisions.

Further, as soon as an issuer delays the disclosure of inside information, a written explanation stating how the delay complied with the legal requirements set out above - legitimate interest, confidentiality, not misleading for the publicshould be created. Issuers should either provide this written explanation to the regulator immediately after information is publicly disclosed, or -depending on the national legal system- keep it on file and provide it to the securities regulator upon request. ${ }^{65}$

European issuers' right to delay disclosure and thereby, restrict all other market participants from trading on that information is essentially another manifestation of the property rights in information theory i.e. information-owners can decide to exercise their property right in socially valuable information they are (in the process of) creating by preventing third parties from trading on it. European regulators have granted the right to delay disclosure and exclude other traders from trading on valuable proprietary information because otherwise, firms would have little motivation to invest resources in developing new information that will have a positive effect on the share price and benefit share-

63 Art. 17(4) Regulation (EU) 596/2014.

64 European Securities and Markets Authority, MAR Guidelines: Delay in the Disclosure of Inside Information, 2016, 4-5, <https://www.esma.europa.eu/sites/default/files/ library/2016-1478_mar_ guidelines_-_legitimate_interests.pdf $>$ (last accessed on 27 November 2019).

65 Art. 17(4) Regulation (EU) 596/2014. 
holders (e.g. acquiring a competitor, pursuing a land acquisition program after discovering valuable metal deposits or discovering a new product).

However, once the reasons for keeping the information private cease to exist (i.e. the share purchase agreement for acquiring a competitor is signed and all regulatory approvals are obtained, the purchase of the land with valuable metal deposits is completed or the acquisition of intellectual property rights with respect to a newly developed product is secured), the firm has to promptly make the inside information public in order to ensure information symmetry across market players.

In the pre-disclosure phase, information-owners need not keep the information they have produced to themselves but may decide to share it (selectively) with third parties of their choosing to the extent such information disclosure is consistent with, or is in furtherance of, the objectives they aimed to achieve by developing the information in the first place. ${ }^{66}$ This manifestation of the property right in information is also reflected in the provisions of the Market Abuse Regulation, setting out European issuers' right to selectively share inside information with individual market participants, provided the recipient of the information is bound by a (contractual or legal) duty of confidentiality towards the issuer. ${ }^{67}$

Allocating the discovery value of new information to the firm, however, is not an inevitable public policy choice and has been the subject of considerable scholarly debate. Under an alternative approach, the firm may decide to disclose and allocate trading rights of inside information to insiders (corporate officers, managers) as a form of executive compensation..$^{68}$ Compensating managers through inside information, however, can be an inefficient (and a nontransparent) compensation mechanism as it would incentivize managers to undertake riskier projects, give priority to their own investment plans and delay disclosure of material information. ${ }^{69}$

$66 \operatorname{Morgan}$ (fn. 2), 99-101 (arguing that owners of information should be allowed to use the information in a manner that is in their best interest).

67 Art. 17(8) Regulation (EU) 596/2014.

68 Macey, "Insider Trading: Economics, Politics and Policy", The AEI Press, Washington D.C., 1991, 11 (arguing that allowing insiders to trade on nonpublic firm-specific may lead to more efficient stock prices as their execution of share trades shall move the price in the right direction); but, see Goshen/ Parchomovsky (fn. 3), 1256-1258 (arguing that insiders may time their trades in a manner beneficial to them and delay trading on inside information, thereby decreasing market efficiency; they also suggest that for the purposes of achieving efficiency on the capital and information markets, property rights in inside information should be allocated to analysts as opposed to insiders).

69 Easterbrook (fn. 1), 332-335; Jesse M. Fried, "Insider Trading via the Corporation", University of Pennsylvania Law Review 162 (2014), 801, 807 (arguing that insider trad- 


\section{Market Sounding / Wall-Crossing}

Initial and Secondary Securities Offerors. Aside from ordinary securities trading, issuers in initial public offerings of securities as well as secondary offerors of financial instruments may want to disclose their intent and the parameters (price, size and structure) of an upcoming securities offering to public investors in order to gauge their interest. Market sounding, thus, creates the risk of unlawful disclosure of inside information to a limited number of investors potentially interested in the upcoming securities offering, in violation of the EU selectively disclosure ban and the tipping ban.

Nonetheless, the Market Abuse Regulation allows securities offerors to wallcross potential investors and to disclose price-sensitive information, provided the recipient investors agree to be wall-crossed and abstain from trading on the basis of the inside information received. Thus, in the parlance of the property rights in information theory, European securities offerors are informationowners that can decide to selectively share the information about their upcoming securities offering with a number of potential investors, while preventing these (potential) investors from trading on this information. Importantly, the market sounding rule also works to encourage and facilitate capital formation on public stock markets.

Takeover Bidders and Parties to a Merger. Takeover bidders and firms intending to merge with another firm may also benefit from the market soundingexception and share inside information about their planned merger or a takeover with the shareholders of the target/merging company(-ies), provided the following two conditions are met. First, the information communicated by the bidder/merging party must be necessary for shareholders to decide whether to sell their shares and second, the shareholders' decision to sell their shares to the

ing may weaken manager's incentives to create firm value and may incentivize managers to engage in short-termism and select less transparent projects); James D. Cox, "Insider Trading and Contracting: A Critical Response to the "Chicago School"”, Duke Law Journal 35 (1986), 628, 655-659 (arguing that if managers were allowed to trade on inside information investors would have difficult time assessing their returns and the compensation that managers receive for their services and that shareholders expect managers to focus on increasing firm's value rather than on their personal investments (via trading on inside information)); see generally Johnatan R. Macey/David D. Haddock, "A Coasian Model of Insider Trading”, Northwestern University Law Review 80 (1987), 1449 (advocating for a contractual approach to insider trading (as opposed to a regulatory ban) and arguing that the outcome of the shareholder-manager bargain would depend on whether managers are risk-averse with respect to receiving compensation in the form of insider trading rights and on whether shareholders would profit from trading on inside information, in the event an insider trading ban with respect to managers is in place). 
bidder/merging party must be reasonably required for the takeover bid or merger to occur.

Market sounding of target shareholders may prove particularly useful in the context of the European corporate landscape, where firm ownership structures are concentrated and characterized by one or more significant shareholders ${ }^{70}$ and where the success of a planned transaction may significantly, or even exclusively, depend on a major shareholder's interest in selling its shares. Gauging the interest of major shareholders before publicly announcing the transaction may, therefore, be critical for the dynamics of the European market for corporate control.

In essence, market-sounding practices with respect to takeover bids and mergers are another example of the operation of the property rights in information approach in the European context. Takeover bidders and merging parties are effectively exempted from the tipping ban and allowed to share inside information about an upcoming takeover or merger with target shareholders. Wallcrossed shareholders, on the other hand, must consent to the wall-crossing and are required not to tip any inside information disclosed to them and keep the disclosed information confidential. ${ }^{71}$ However, investors who need to keep their position in issuer's securities liquid may be reluctant to give such consent as wall-crossing restricts their trading ability. Thus, issuers, secondary offerors and takeover bidders may need to be able to execute the transaction quickly after wall-crossing potential investors as otherwise, investors may otherwise refuse to give their consent.

In any event, the disclosing parties should be careful when deciding the (scope of) information they will reveal to potential investors when soliciting their consent to be wall-crossed. Disclosing the name of the issuing/target company to which the market sounding shall relate to, and the time period for which investors shall remain wall-crossed may qualify as plain disclosure of inside information in the eyes of securities regulators, without qualifying under the market sounding-exception. When asking investors whether they are interested in being wall-crossed, the disclosing parties may, however, give the name of the company in the alternative i.e. by listing several companies, one of which is the actual issuing or target company, as long as this information in conjunction with other publicly available market information does not allow sophisticated investors to make an informed guess about the identity of the relevant company and the nature of the planned transaction.

70 See generally Fabrizio Barca/Marco Becht (ed.), The Control of Corporate Europe, 2012.

71 Art (11)(5)(d) Regulation (EU) 596/2014. 


\section{Investor Activism under European Insider Trading Rules}

In 2018, a record number of activist campaigns were launched at European companies, making Europe the second most frequented region (after the U.S.) for hedge fund activism in terms of capital deployed and number of activist campaigns initiated. ${ }^{72}$ Investor activism can be a collective (rather than an individual) effort of several hedge funds forming a loose association of likeminded investors but falling short of forming a group under ownership reporting rules (wolf packs). ${ }^{73}$ In several European jurisdictions (France, Germany, The Netherlands and Sweden), wolf packs have been reported to account for over $20 \%$ of activist interventions ${ }^{74}$. Critical to the formation of a wolf pack is the lead hedge fund, who first develops an activist strategy with respect to the target firm and makes the initial share acquisition. Other activist funds then follow the lead fund and accumulate a substantive amount of shares in the target, oftentimes prior to lead fund's public disclosure under Section 13D of the U.S. Securities and Exchange Act or the equivalent ownership disclosure regime under the national transparency requirements of EU Member States. ${ }^{75}$

Wolf pack formation may be at odds with the EU insider trading rules in the event the wolf pack is formed by way of the lead hedge fund tipping other hedge funds about its toehold acquisitions and/or activist strategy prior to public announcement. ${ }^{76}$ Additionally, to the extent wolf pack members coordinate their trading activity and the exercise of their shareholder rights in course of an activist campaign, they may also form a group under the EU and national ownership disclosure rules, in which case they are required to notify their joint exercise of shareholder rights to the securities regulator.

72 Lazard's Shareholder Advisory Group, 2018 Review of Shareholder Activism, 2019 <https://www.lazard.com/perspective/lazards-annual-review-of-shareholder-activism2018/> (last accessed on 20 November 2019.

73 John C. Coffee, Jr./Darius Palia, "The Wolf at the Door: The Impact of Hedge Fund Activism on Corporate Governance”, The Journal of Corporation Law 41 (2016), 545, 562; Alon Brav/Amil Dasgupta/Richmond D Mathews, "Wolf Pack Activism", Robert H Smith School Research Paper No. RHS 2529230, 2018, 6 <https://papers.ssrn.com/ sol3/papers.cfm?abstract_id=2529230 > (last accessed on 25 September 2019).

74 Marco Becht/Julian R. Franks/Jeremy Grant/Hannes F. Wagner, "The Returns to Hedge Fund Activism: An International Study”, Review of Financial Studies 30 (2017), 2933, 2938.

$75 I d ., 2950$ (showing abnormal share turnover and abnormal return for European activist interventions 20 days prior to disclosure date).

76 Yu Ting Forester Wong, "Wolfs at the Door: A Closer Look at Hedge Fund Activism", Management Science 66(6) (2020), 2347, 2349 (providing empirical evidence that wolf packs are formed as a result of coordinated effort between hedge funds prior to public (13D) disclosure of the lead hedge fund). 
In light of the foregoing, this section engages in an insider trading analysis of hedge fund activists' practices. More specifically, in sub-section I infra, I analyze activist campaigns through the lens of the inside information-definition under the Market Abuse Regulation and conclude that activist campaigns would likely qualify as inside information in the pre-disclosure phase (i.e. prior to their public announcement). In sub-section II, I consider whether trading on the basis of information about a planned activist campaign is allowed under the Market Abuse Regulation.

\section{Activist Campaigns as Inside Information}

Nowadays, the securities markets landscape is densely populated with hedge fund traders and active mutual fund traders, executing a substantive volume of securities trades on any given day. Hedge fund managers research securities in the hope of identifying underperforming and/or undervalued firms and on that basis, make investment decisions and execute securities trades. By developing an investment strategy, active investors essentially produce new information about specific securities and acquire informational advantage over other market participants. To the extent such informational advantage qualifies as inside information, executing trades in line with this investment strategy may constitute insider trading under the parity-of-information theory.

Further, hedge fund managers regularly receive firm-specific information in communications with firm's corporate officials, and while issuers have a duty not to selectively disclose inside information to (potential) investors, such disclosures may either occur inadvertently or when several bits of non-material information, in their totality -and when in the hands of a sophisticated investor- amount to a disclosure of a material nonpublic (inside) information. In fact, hedge fund managers have recently become a frequent target of securities regulators for insider trading violations, both in the U.S. and in the EU. ${ }^{77}$ And while some of this regulatory action involves clear-cut insider trading violations such as conspiracies and sophisticated insider-trading rings, other cases are more representative of the intricacies of applying insider trading to activist investors that collect information from different sources before adopting a trading strategy. The two key considerations for active investors under the EU insider trading rules are: (i) whether active investment strategies qualify as in-

77 See generally Andrew N. Vollmer, "How Hedge Funds Advisers Can Reduce Insider Trading Risk”, Journal of Securities Law, Regulation and Compliance 3 (2010), 106; Lynn Stout, "How Hedge Funds Create Criminals", Harvard Business Review Blog, 2010, <https://hbr.org/2010/12/how-hedge-funds-create-crimina> (last accessed on 10 November 2019). 
side information, and if yes, (ii) whether trading on their proprietary investment strategies qualifies as insider trading.

An information qualifies as inside information under the Market Abuse Regulation if it is (i) nonpublic, (ii) precise, (iii) price-sensitive, and (iv) relating to one or more issuers or financial instruments. I analyze the first three elements in the next subsections.

\section{Nonpublic Information}

A central tenet of informational parity is the equality of information that investors can access and base their trading decisions on. Timely, comprehensive and non-discriminatory disclosure of relevant information is, therefore, a key component of any regulatory system whose primary goal is to level the informational field between securities traders. In the sub-sections that follow I analyze the challenges faced by EU policymakers in properly defining and implementing information disclosure on the European capital markets in the current environment of technological advancement and hedge fund activism.

\section{a) Scope of Information Dissemination}

From the perspective of European issuers of securities and in the context of complying with their continuous disclosure obligations discussed in section B.I supra, European issuers are required to make a wide and simultaneous dissemination of inside information across the EU, in a manner that is as fast as possible, non-discriminatory and free of charge..$^{78}$ Public disclosure through the media is mandated and should include media outlets reasonably relied upon by investors that ensure effective dissemination of the inside information to the public. ${ }^{79}$ These public disclosure standards, however, are only relevant for the assessment of issuers' compliance with their continuous disclosure requirements and only with respect to information directly relating to the issuer. ${ }^{80}$ Information that only indirectly concerns the issuer falls outside the scope of issuer's disclosure obligations, such as market information produced by other market participants, governments, central banks, (un)regulated market authorities, rating agencies or stock exchanges. ${ }^{81}$

78 Art. 1(1)(a) Implementing Regulation (EU) 2016/1055.

79 Id., Art. 1(1)(b).

80 See supra B.I.

81 Chiarella (fn. 23), 231 (providing that the "market information" upon which the petitioner relied "did not concern the earning power or operations of the target company, but only the plans of the acquiring company; Stephen M. Bainbridge, "An Overview of 
From the perspective of securities traders, there is no specific guidance on EU level as to when an information is considered public and can be traded on. On a national level, the British regulator provides more certainty in this respect, stipulating five categories of public information that market actors can freely trade on. First, information disclosed to regulated markets using a designated information service for disseminating regulated information. Second, information contained in public records that are open for inspection by the public. Third, information available through the internet, in a publication available upon a payment of a fee or derived from other public information. Fourth, information that can be obtained by observing members of the public, without infringing rights/obligations to privacy, property or confidentiality. Lastly, information that can be obtained by analyzing or developing other information which is generally available. ${ }^{82}$ These criteria are applicable regardless of whether the information may be available only outside the U.K. or only a person with superior resources, skill and competence may be able to develop. ${ }^{83}$

\section{b) Corporate Access}

Unlike ordinary retail investors, sophisticated institutional investors regularly meet with issuer's management, either as part of investor conferences or road shows. ${ }^{84}$ These direct investor-management interactions are typically organized by brokerage-houses ${ }^{85}$, in the expectation that they will be compensated in the form of trading commissions. ${ }^{86}$ Advanced regulatory systems would ordinarily have in place legislation that ensures that this private access to management does not result in informational advantages being conferred to a privileged group of investors.

US Insider Trading Law, Lessons for the EU?” UCLA School of Law, Law-Econ Research Paper no. 05-5, 2005 <https://papers.ssrn.com/ sol3/papers.cfm?abstract_ $\mathrm{id}=654703>$ (last accessed on 20 November 2019); Karmel (fn. 1), 86-87.

82 MAR1.2.12 E, FCA Handbook (fn. 47).

83 Id., MAR 1.2.13 E.

84 Bank of America Meryl Lynch, Global Roadshow Report 2017, 2018, 3 <https://www. irmagazine.com/research-reports/global-roadshow-report-2017> (last accessed on 15 October 2019 (showing that $91 \%$ of European companies across all market capitalization-categories, went on a roadshow in 2017.

$85 I d ., 5$ (even though over $90 \%$ of companies use brokerage houses for road shows, the majority of the companies conducting road shows in parallel, directly invite investors).

86 T. Clifton Green/Russell Jame/Stanimir Markov/Musa Subasi, "Access to Management and the Informativeness of Analysts' Research”, Journal of Financial Economics 114 (2014), 239, 240 (showing that conference-hosting brokers issue more accurate earnings forecasts). 
Yet, even if issuers do not selectively disclose material nonpublic information in private meetings at investor conferences, professional investors can still benefit from their participation to investor conferences by asking specific questions and obtaining answers that may be relevant only in conjunction with their private information or by getting "nonverbal cues in a less rehearsed setting" ${ }^{87}$ In fact, empirical evidence shows that investors with access to invitation-only conferences have significant trading gains in the period of three to thirty days after the conference, provided they participated in off-line meetings with management i.e. outside of the webcast portion of the conference to which any investor can tune in and the CEO of the firm is present at the conference. $^{88}$

Private meetings with management are, however, valuable mostly to sophisticated investors (hedge funds) that have the resources, skill and time to initially develop private information, and thereafter, under a mosaic approach for developing an investment strategy, obtain new -albeit nonpublic and nonmaterial- information or to verify existing information at a private investor meeting. ${ }^{89}$ Over half of management's private investor meetings are with hedge funds ${ }^{90}$, who have been shown to be the only investor class to make improved trades in the period following investor meetings, relative to other investor classes attending private meetings with companies. ${ }^{91}$

Hedge funds should nonetheless be mindful of the fact that nonpublic material information may be disclosed during private meetings, in which case they should refrain from trading on this information. The experience with the British regulator shows that hedge fund managers' sophistication shall be taken into account when deciding whether a disclosure of inside information can be deduced from communications with management, even if such inferences are based on several bits of information, none of which qualifies as an inside information on its own. ${ }^{2}$

87 Brian J Bushee/Micabel J. Jung/Gregory S. Miller, "Do Investors Benefit from Selective Access to Management”, Journal of Financial Reporting 2 (2017) 31, 35.

88 Id.

89 Martin Brengtzen, "Private Investor Meetings in Public Firms: The Case for Increasing Transparency”, Fordham Journal of Corporate \& Financial Law 2017, 33, 54.

90 Id., 36; Steve Johnson, Hedge Funds Have Greater Access, Financial Times, 3 June 2013 $<$ https://www.ft.com/content/cd6cd5bc-c9fd-11e2-af47-00144feab7de> (last accessed on 25 September 2019).

91 David Solomon/Eugene Soltes, "What are we meeting for? The Consequences of Private Meetings with Investors”, Journal of Law and Economics 58 (2015), 325, 328.

92 Financial Services Authority, Decision Notice to David Einhorn, 2012, $9<$ https://www. fca.org.uk/publication/decision-notices/dn-einhorn-greenlight.pdf $>$ (last accessed on 20 November 2019). 


\section{Precise Information}

The insider trading prohibition does not extend to trading on rumors, speculations or information of otherwise uncertain nature. This is because, the insider trading prohibition under the Market Abuse Regulation works only if the "precise-information" test is satisfied. This test essentially requires that the information is associated with (i) a set of circumstances or events that have occurred or may be reasonably expected to occur, and (ii) that they are specific enough to allow for an assessment of their effect on securities prices. ${ }^{93}$

As to the first prong of this test, regulators will require that there is a firm and objective evidence proving the existence of the circumstances or events in question. Only evidence available ex ante i.e. at the time the alleged insider trading violation took place, shall be considered. ${ }^{94}$ With respect to information relating to circumstances or events that occur through protracted processes, the intermediate steps leading to the circumstance or event in question may also qualify as precise information. ${ }^{95}$

The second prong of the test i.e. whether the event is specific enough to allow an assessment of its effect on prices can be satisfied if (i) a reasonable investor can make an investment decision on the basis of this information with no risk (or very low risk) or (ii) the information would likely be immediately exploited by the market, if made publicly available. ${ }^{96}$

Application to Activist Investment Decisions and Trading Strategies. Active investment decisions can easily qualify as "precise" information under the Market Abuse Regulation. Securities market participants, and active investment funds in particular, are by now well aware of hedge funds' investment tactics, which typically involve acquiring a toehold in an underperforming target and subsequently, initiating a campaign with the aim of implementing operational changes and improving the share price. Therefore, as soon as the information about the hedge fund's investment is made public (or beforehand, potentially in violation of the tipping ban) other (actively managed) investors start acquiring shares in the target company in expectation of profiting after the hedge fund strategy is implemented. This is a clear indication that the information that an activist campaign is underway is specific enough for other market participants to make investment decisions on this basis and are, in reality, imme-

93 Art. 7 Regulation (EU) 596/2014.

94 CESR Guidance (fn. 36), 5.

95 Art. Regulation (EU) 596/2014.

96 CESR Guidance (fn. 36), 5; Blanaid Clarke, "Inside Information and the European Market Abuse Directive” in Paul U. Ali/Greg N. Gregoriu (ed.), Insider Trading: Global Developments and Analysis, 2006, 99-128. 
diately exploiting this information by accumulating target's shares ${ }^{97}$, resulting in abnormal returns in the period before and after the public disclosure of hedge fund's share acquisitions. ${ }^{98}$

Activists, however, cannot fully predict how their intervention will eventually play out as the course of the campaign will depend on target management's responsiveness to activists' demands, hedge fund's own preference for pursuing a particular tactic (and for confrontation with incumbent management) and the role other active investors shall play during the intervention. Empirical evidence shows that over two-thirds of activist campaigns end without any formal demands, and of those exacting specific actions from the target less than $20 \%$ require board representation, $10-12 \%$ threaten a proxy contest and only $7 \%$ engage in a proxy fight with management. ${ }^{99}$

According to the EU insider trading rules, however, the information need not be comprehensive or detailed in order to qualify as precise and it may not even be definitive i.e. it can include alternative scenarios. ${ }^{100}$ Therefore, the activist's accumulation or intention to accumulate target's shares and launch a campaign shall likely, on its own, qualify as precise information even if the activist changes its strategy in course of the campaign by making different demands than initially planned, launches a takeover bid for the target, or simply decides to exit the target without engaging in a proxy fight or obtaining a seat on the board.

97 Becht/Franks/Grant/Wagner (fn. 74), 2935, 2951; Wong (fn. 76), 2351 (Becht/Franks/ Grant/Wagner provide empirical evidence of abnormal share accumulation around the disclosure date whereas Wong provides evidence of abnormal share turnover of $325 \%$ on the trigger date (i.e. date on which the ownership reporting obligation is triggered and a filing has to be made within ten days)).

98 See Alon Brav/Wei Jiang/Frank Partnoy/Randall Thomas, "Hedge Fund Activism, Corporate Governance and Firm Performance", The Journal of Finance 63 (2008), 1729 (showing that the average BHAR is $7.2 \%[+2 ;+20]$ for a sample of 1059 events of hedge fund activism at U.S. companies in the period from 2001 to 2006); see also Marco Becht/Julian Franks/Jeremy Grant, "Hedge Fund Activism in Europe", (ECGI Finance Working Paper No. 283/2010, 2010), <https://papers.ssrn.com/sol3/papers. cfm?abstract_id=1616340\#\#> (reporting a mean CAR of 4.4\% [-20;+20] across European jurisdictions, and more specifically a mean CAR of $2.7 \%$ in France, $6 \%$ in Germany, $2.6 \%$ in Italy, $14.8 \%$ in Sweden, $15.8 \%$ in Switzerland and $2.8 \%$ in the U.K. on the basis of.305 in the period from 2000 to 2008).

99 Gantchev (fn. 52), 612.

100 CESR Guidance (fn. 36), 5; Clarke (fn. 96), 99-128 (discussing when information would satisfy the "precise-information" test under Directive 2003/6/EC). 


\section{Price-Sensitive Information (the "Materiality" Test)}

In addition to being nonpublic and precise, an information has to have a significant effect on the price of securities before it can qualify as inside information. ${ }^{101}$ Under the reasonable investor test set forth in the Market Abuse Regulation, an information has a significant effect on prices if "a reasonable investor would be likely to use it as part of the basis of his or her investment decisions". ${ }^{102}$ The assessment of whether the requirements of the test are met ought to be made on an ex ante basis i.e. considering the likelihood, at the time inside information was used, that the information in question would have a significant price effect, if made public. In making this assessment, a certain degree of certainty is required i.e. knowing the price effect with certainty is not necessary, but a mere possibility of a significant price effect would not suffice for the purposes of the "reasonable investor" test.

European securities regulators have rejected the idea of introducing a fixed threshold of price movements or a quantitative criteria to determine whether a significant price effect could have been predicted. ${ }^{103}$ This is mainly because such a clear-cut criteria would likely prejudice smaller companies that experience higher volatility of their shares compared to large-cap companies where small price movements may qualify as "significant", for the purposes of the "reasonable investor" test. ${ }^{104}$

The price effect of a specific information would normally be a function of the size of the impact that the underlying event and/or circumstance would have on the issuer's overall activity, the relevance of the information for the assessment of the share price, and the reliability of the source of the information. Regulators would also look at past price sensitivity of the same type of information, whether the issuer has qualified similar information as inside information, or if the analysts' reports would suggest that the information may be price sensitive. ${ }^{105}$

Application to Activist Investment Decisions and Trading Strategies. Activist investors direct their resources to a limited number of interventions and typically hold shares and pursue interventions in less than ten targets at a time. ${ }^{106}$ They demand important changes in the target's operations, capital structure or

101 Art. 7(1) Regulation (EU) 596/2014.

102 Art. 7(4) Regulation (EU) 596/2014.

103 CESR Guidance (fn. 36), 6.

104 Id.

105 Id.

106 Marco Becht/Julian R Franks/Colin Mayer/Stefano Rossi, "Returns to Shareholder Activism, Evidence from a Clinical study of the Hermes UK Focus Fund”, Review of 
board governance. As a result, activist share acquisitions in target's securities are associated with an abnormal return around the date of public disclosure and following the implementation of specific outcomes at the targeted firm. ${ }^{107}$ Against this empirical background, activists' trades and their prospective intervention at the target firm can easily qualify as events with significant price effect on company's shares.

Recently, however, traditional long-term institutional investors (mutual funds, pension funds) with typically passive investment styles, have taken up activist roles at investee companies either by voicing their position with respect to an ongoing proxy fight, an M\&A-event or by directly engaging in board nominations. ${ }^{108}$ First-time or "occasional" activists ${ }^{109}$ are now performing proprietary research on their investments and adopt their own decisions with respect to investee companies. Information about their engagement with other hedge funds in furtherance and/or support of their strategy or the adoption of their own active strategy may also qualify as inside information.

Outside of the activism context, share acquisitions by passive institutional investors would less likely satisfy the significant price effect-requirement, in particular if the size of their shareholding is below the regulatory reporting threshold. For example, mutual funds-due to their business model- have lower incentives to create value in investee companies ${ }^{110}$ and do not target underperforming companies at the time of their initial investment for the purpose of

Financial Studies 22 (2009), 3093 (reporting four to eight new investments per year for the UK Focus Fund).

107 See Becht/Franks/Grant/Wagner (fn. 74), 29 (showing that the abnormal returns of European firms around beneficial ownership disclosure of hedge fund activists is $4.8 \%$ and that the aggregate abnormal returns associated with different outcome-related announcements is $8.8 \%$ ).

108 Lazard's Shareholder Advisory Group, Quarterly Review of Shareholder Activism Q1 2019, 2019, 5, <https://www.lazard.com/perspective/lazards-quarterly-review-ofshareholder-activism-q1-2019/> (last accessed on 20 November 2019 (describing the interventions of Neuberger Berman at Ashland and of Wellington Management at Bristol-Meyers Squibb, as examples of active investors entering the activist fray by demanding specific board actions).

109 David Benoit, “Don't Make Me Do This, Rise of the Reluctant Activist", The Wall Street Journal, 18 February 2016, <https://www.wsj.com/articles/dont-make-me-dothis-rise-of-the-reluctant-activist-1455814599> (last accessed on 20 November 2019); Josh Black, “The Activist Investing Annual Review 2017”, Harvard Law School Forum on Corporate Governance and Financial Regulation, 2017, <https://corpgov.law. harvard.edu/2017/02/21/the-activist-investing-annual-review-2017/> (last accessed on 19 November 2019 (arguing that "occasional" activists made the highest number of governance-related demands at 311 companies in 2017).

110 See generally Wei Yiang/Hyunseob Kim/Alon Brav, "Hedge Fund Activism - A Review”, Foundations and Trends in Finance 4 (2010), 1. 
implementing changes that will increase the target firm's share price. They may, however, subsequently take up a more active or even activist role, if the performance of the firm starts declining or a major corporate development is underway (e.g., hedge fund intervention, hostile takeover).

\section{Trading on Active Investment Strategies under the EU Market Abuse Regulation}

When actively managed funds perform research, and on that basis adopt investment decisions that involve trading in the shares of a specific target company, they are in fact producing new (market) information with respect to the securities issued by that target company. As discussed in the foregoing subsection, this informational advantage for activist investors would likely qualify as inside information under the EU insider trading rules. This is particularly the case with hedge fund activist campaigns as they tend to have significant price effect on securities, in addition to being a nonpublic and precise information.

The British financial regulator specifically clarified the application of market abuse rules to shareholder activism in a 2007 newsletter and stated that even if an activist strategy involving the exercise of shareholder rights and a corporate re-structuring of the target that is developed on the basis of activist's own expert analysis qualifies as inside information, the activist can use this informational advantage and trade "on the basis of its intentions and knowledge of its strategy" without violating market abuse rules. ${ }^{111}$ The British regulator, however, took the analysis one step further and argued that activist investors cannot share (tip) their investment and trading strategies to like-minded investors, prior to publicly disclosing their intervention. ${ }^{112}$ In section E infra, I analyze this interpretation of the tipping ban to activist investor communications from the perspective of the property rights in information theory.

111 Financial Services Authority, Market Watch, Markets Division: Newsletter on Market Conduct and Transaction Reporting Issues, Issue No. 20, 2007

<http://www.fsa.gov.uk/pubs/newsletters/mw_newsletter20.pdf> (last accessed on 1 June 2018).

112 Id., 1. 


\section{E. Applying the Property Rights in Information Theory to Hedge Fund Activism: Extensions}

Important insider trading issues pertain to hedge fund activism prior to the launch of an activist campaign and in the pre-disclosure phase of an activist campaign. Insider trading rules dictate whether activists can disclose their plans for an intervention at a target firm to other (active/activist) current or potential investors in order to hear their views and/or solicit their support, and whether these investors can subsequently trade on the activist investor's strategy and potentially, create a wider investor coalition in this pre-disclosure phase of activist interventions. In the subsequent sub-sections, I explain how the current EU insider trading rules based on the equal access-approach shape investor communications prior to the public announcement of an activist intervention, and how these regulatory outcomes would be different under a property rights-approach.

\section{The Case for Allowing Selective Disclosure of an Activist Strategy}

As was discussed earlier, the use of hedge fund's own activist strategy to trade in target firm's shares does not amount to insider trading under EU regulations. The EU policy-makers have not provided a doctrinal rationale for introducing this exception to the parity-of-information theory and in the preceding sections I have argued that trading on informational advantages arising out of one's own investment research and trading decisions is best explained under the property rights in information theory.

The issue that subsequently arises, however, and is particularly relevant in the context of wolf packs of activist investors, is whether market professionals that have developed their own investment strategy should have the right to share this strategy with other market participants, provided disclosing their strategy to third parties advances their (activist) agenda. Under the Market Abuse Regulation, sharing of inside information constitutes tipping and is unlawful, regardless of whether the tippee subsequently trades on the basis of the tip or not. ${ }^{113}$

113 Under Regulation (EU) 596/2014 market participants may disclose inside information in the normal exercise of an employment, a profession or duties. Hedge funds' tipping their investment strategy to other (hedge) funds prior to public disclosure, however, would have a hard time invoking this exception to justify their pre-disclosure communications of inside information (their investment and trading strategy) under EU rules; see Art. 10(1) Regulation (EU) 596/2014. 
Yet, (lead) hedge funds may have important incentives to share their activist strategy with other hedge funds and/or institutional investors, prior to deciding and/or publicly announcing an activist intervention. ${ }^{114}$ Reliance on other investors' support may be key for a successful activist campaign given that hedge funds hold minority positions in target firms (at around $6 \%)^{115}$ and typically cannot control the outcome of the campaign, should there be a shareholder vote on a particular matter. ${ }^{116}$

Moreover, it is not only hedge funds that rely on a support by a wider shareholder base but also institutional investors - who are sophisticated enough to evaluate the merits of an activist campaigns but operate on a business model that is generally inconsistent with active shareholder ownership - oftentimes rely on hedge fund activists to detect underperforming areas in firms' opera-

114 Randal Thomas/Paul Edelman, "Shareholder Voting in the Age of Intermediary Capitalism”, Southern California Law Review 87 (2014), 101, 157 (discussing how hedge funds need the support of institutional investors in order to have a successful campaign and that in practice, hedge funds would approach institutional investors before approaching the company in order to solicit their support); see generally John C. Coffee/Robert J. Jackson Jr./Joshua Mitts/Robert E. Bishop, "Activist Directors and Agency Costs: What Happens When an Activist Directors Goes on the Board?”, Columbia Business School Research Paper No. 18-15, 2018, <https://papers.ssrn.com/ sol3/papers.cfm?abstract_id=3100995> (last accessed on 10 November 2019) (arguing that a hedge fund employee holding a board seat shares nonpublic information with other hedge funds and that this information leakage holds the wolf pack together); see generally Alon Brav/Wei Jiang/Tao Li/James Pinnington, "Picking Friends Before Picking (Proxy) Fights: How Mutual Fund Voting Shapes Proxy Contests”, Columbia Business School Research Paper No. 18-16, 2018, <https://papers.ssrn.com/sol3/ papers.cfm?abstract_id=3101473> (last accessed on 25 September 2019 (finding that active funds are more likely to vote for shareholder activists than passively-managed funds and that mutual funds are more likely to support hedge funds than other types of shareholder proponents. In light of these shareholder voting preferences, the authors show that for hedge funds deciding on whether to pursue an activist campaign with respect to a potential target firm, it is critical whether the type of investors holding shares in the target firm would typically support an activist campaign).

115 Lucian A. Bebchuk/Alon Brav/Robert J. Jackson Jr./Wei Jiang, "Pre-Disclosure Accumulations by Activist Investors: Evidence and Policy”, Journal of Corporation Law 39 (2013), $1,5$.

116 See generally Alon Brav/Wei Jiang/Frank Partnoy/Randall Thomas, "The Returns to Hedge Fund Activism”, Financial Analysts Journal 64 (2008), 45 (providing empirical evidence that activists are (fully or partially successful at their demands in two-third of the cases); Marcel Kahan/Edward Rock, "Hedge Funds in Corporate Governance and Corporate Control”, University of Pennsylvania Law Review 155 (2007), 1021, 1090 (arguing that activists influence but do not control corporate policy and that their success is dependent on the support of other institutional investors). 
tions, submit shareholder proposals and/or initiate proxy fights. ${ }^{117}$ Thus, the current EU tipping ban may have a chilling effect on shareholder activism and investor cooperation. It could potentially also serve as a barrier for investors intending to form group under ownership reporting rules as their pre-notification communications may be in violation of the tipping ban under the Market Abuse Regulation, provided price-sensitive, nonpublic information is disclosed between the cooperating parties.

On the other hand, allowing activist investors to disclose their strategy to selected investors would be consistent with the property rights in information theory. Having produced an informational advantage with the adoption of an activist strategy, hedge funds should have the right to control the scope of dissemination of their strategy and exercise property rights in this information that are best aligned with their incentive to discover socially valuable information in the future. Collaborating investors that jointly develop a proprietary investment strategy would be granted joint ownership over their strategy.

To be sure, the Market Abuse Regulation already provides several instances where market actors (issuers, secondary offerors, takeover bidders and merging parties) that have developed new material information may selectively disclose this information for the purposes of gauging investors' interest in a specific transaction (IPO, secondary offering of securities, takeover bid or a merger) prior to public announcement of the transaction. These market participants can wall-cross other investors, to the extent necessary for the success of the transaction. The recipient parties would then have to commit to keep the information confidential and not trade on it.

Activist investors may also benefit from an exception from the tipping ban along these lines. Being able to conduct a market sounding of their campaign, obtain the opinion of target firm's investors with respect to a prospective intervention and solicit support for the interventions, may further enable activist investors to tailor successful campaigns backed by the shareholder base of the target firm, while eliminating coordination problems by small (and passive) shareholders. Activist funds regularly engage in this type of pre-marketing activities and discuss their activist plans with private equity and other hedge funds in jurisdictions -such as the United States- where these communications typically are not violating applicable securities regulations. ${ }^{118}$

117 Alon Brav/Wei Jiang/Frank Partnoy/Randall Thomas, "Hedge Fund Activism, Corporate Governance, and Firm Performance”, Journal of Finance 63 (2008), 1729, 1730.

118 Susan Pulliam/Juliet Chung/David Benoit/Rob Barry, "Activist Investors Often Leak Their Plans to a Favored Few”, The Wall Street Journal, 26 March 2014, <https:// www.wsj.com/articles/activist-investors-often-leak-plans-to-peers-ahead-of-time1395882780> (last accessed on 23 September 2019) (discussing how Jana Partners in- 
One may argue that by relaxing insider trading rules in the context of investor communications, the management of target firms is "kept in the dark". Yet, not all activist strategies are hostile and hedge funds oftentimes choose to engage in a constructive dialogue with management before publicly venting their discontent with, and demands vis-à-vis target management. There are numerous instances of hedge funds approaching management first in an attempt to jointly work towards implementing changes in underperforming areas of operation. ${ }^{119}$ In addition, nowadays it is a good corporate governance practice for management to pre-empt activist interventions by regularly meeting current and potential investors to present their long-term perspective of the business they are managing and discuss investors' questions and address their concerns. ${ }^{120}$ Thus, it could be argued that shareholder-management communication has improved as a by-product of hedge fund campaigns.

However, in the event dissident investors and firm's management have contrasting views on a specific issue that also involves inside information, the Market Abuse Regulation provides different tools to activists and firms management. Firms (securities issuers) can make onward selective disclosures to any third party as long as the recipient party is bound by a confidentiality obligation. ${ }^{121}$ On the other hand, activist funds (and market participants generally) may not share price-sensitive information with third parties (except as part of one's employment, profession or duties), which arguably distorts the levelplaying field between (target's) corporate board and activist investors in the pre-disclosure phase of an activist intervention.

Thus, a policy proposal that is based on the property rights approach and grants activist investors the right to share their activist strategy with other market participants -to the extent necessary for furthering their activist agenda and while keeping the information confidential- can level the playing field between targeted firms and hedge funds in activist interventions and is consistent with

formed Elliott Management that it has acquired a position on Juniper Networks before this information became publicly known and that Elliott Management also consults about its forthcoming investments in target firms with private equity investors).

119 This is particularly the case in the EU where activists are not required to disclose their intentions with respect to a target firm when notifying their share acquisitions and in instances where activist hold an ownership stakes that is below the regulatory reporting threshold; see Marco Becht/Julian Franks/Jeremy Grant, "Hedge Fund Activism in Europe: Does Privacy Matter” in Jennifer G.Hill/Randall Thomas (ed.), Research Handbook on Shareholder Power, 2015, 116-128.

120 Martin Lipton, Corporate Governance: The New Paradigm, Harvard Law School Forum on Corporate Governance and Financial Regulation, 2017, <https://corpgov.law. harvard.edu/2017/01/11/corporate-governance-the-new-paradigm/> (last accessed on 5 October 2019).

121 See supra fn. 67 and accompanying text. 
the property rights allocated under the Market Abuse Regulation to other information-owners (issuers, bidders, secondary offerors, merging parties) to selectively share inside information in order to successfully execute a transaction prior to public announcement.

\section{The Case for Allowing Tippees to Trade on an Activist Strategy}

Empirical evidence shows that a lead hedge fund that has identified an underperforming target has a higher chance of succeeding in his demands vis-à-vis target management and obtaining board representation if other hedge funds also accumulate shares and join in the activist campaign. ${ }^{122}$ Campaigns involving multiple activist investors are also a more profitable engagement type compared to single-fund campaigns and are associated with higher abnormal returns throughout the activist campaign. ${ }^{123}$

Under the property rights in information theory, nonpublic material information is an asset and the creators thereof should be able to exploit the information the way they see fit i.e. by a sale, gift or as part of executive compensation for services rendered. ${ }^{124}$ Yet, only transferring (tipping) inside information about an upcoming activist intervention from information-owners to other institutional investors is of little value for the investors on the receiving end if they cannot trade on it, or if by virtue of possessing this information they would effectively become insiders and cannot dispose of their holdings at will. Clearly, such restrictions would also prevent the formation of wolf packs, decrease the chances for success of activist campaigns and decrease the incentives of hedge funds leading the pack to develop new information in the future.

This is the approach followed under the EU insider trading regulation. Information-owners (including activist investors) are prohibited from sharing inside information and subsequently, from allowing their tippees to trade on that information as this would be inconsistent with the tipping ban and the insider trading ban. One may argue, therefore, that when deciding between the competing goals of promoting investor confidence in the European capital markets as opposed to increasing the efficiency of the market for corporate influence (i. e. the market for investor activism), EU policymakers have decided in favor of the former.

123 Id., 2349, 2365(showing that wolf packs have 8.4\% higher abnormal buy-and-hold returns in course of the campaign and that the marginal effect of the wolf pack on the success of the campaign and on the likelihood of obtaining a board seat is positive and significant at $7.5 \%$ and $8.5 \%$ respectively). 
Yet, under a property rights account, the goals of promoting investor confidence in the integrity of capital markets and efficiency in the market for corporate influence need not necessarily conflict. ${ }^{125}$ Investor confidence will not be undermined if activists, in their capacity as information-producers/information-owners of socially valuable information developed through their diligence and skill, disclose this information to other investors that further their agenda in course of an activist campaign. To the contrary, gaining support in the predisclosure phase of an activist intervention would increase active investors' incentives to engage in costly research of listed securities, while at the same time improving share price accuracy that is concomitant to informed trading by knowledgeable investors. Ultimately, efficient capital markets are to the benefit of all securities holders, including smaller asset managers that by resolving to support a specific activist campaign portray themselves as "skilled" managers in the eyes of the asset owners (provided the campaign is successful) as opposed to "unskilled" asset managers who refrain from engaging in activist campaigns. ${ }^{126}$

More recently, and as the number of asset managers and the capital they raise reaches record high levels (whereas the number of potential targets stays roughly the same), activists happen to research the same companies and to the extent a rival hedge fund is faster in making its campaign publicly known - and causes the target firm's share price to increase - other hedge funds intending to also launch a campaign with respect to the same target, may have to either abandon their campaign or execute it at a later point in time when the share price stabilizes or decreases to pre-announcement levels. ${ }^{127}$ To be sure, parallel activist campaigns do not always have the same or similar goals and hedge funds may even make opposing demands to target's management. ${ }^{128}$ Thus, it is likely that a certain level of coordination between hedge funds pursuing a common agenda exists and that wolf packs are more likely to be formed between

125 See Brian. R. Cheffins/John Armour, "The Past, Present and Future of Shareholder Activism by Hedge Funds”, Journal of Corporation Law 37 (2011) 51, 58-60 (introducing the concept of the "market for corporate influence" to distinguish offensive hedge funds' tactics from corporate control acquisition (i.e. " the market for corporate control) as a means for implementing change at target firms).

126 Brav/Dasgupta/Mathews (fn. 73), 6.

127 Soyoung Kim/Olivia Oran, “Activist Investors Bump into Each Other in Campaigns”, Reuters, 17 March 2014, <https://www.reuters.com/article/us-activists-campaigns/ac tivist-investors-bump-into-each-other-in-campaigns-idUSBREA2GOKU20140317> (last accessed on 5 November 2019).

128 Thomas/Edelman (fn. 114), 156-157 (discussing how different investor preferences with respect to a specific voting matter weaken the collective outcome of the shareholder vote). 
activist investors that have a history of pursuing activist campaigns at the same target firms . ${ }^{129}$

Interestingly, even though EU insider trading rules allow information-owners in contexts other than investor activism to share the information they have produced with third parties (market sounding, issuer's right to selectively disclose inside information), market participants on the receiving end of that disclosure may still not trade on the basis of the information disclosed (the tip). Takeover bidders, for example, may trade on their own takeover strategy and acquire shares in the target company prior to publicly announcing the takeover bid without disclosing their takeover plans to the market. They can even conduct market sounding and wall-cross target shareholders, to the extent necessary to launch a successful takeover bid. ${ }^{130}$ However, wall-crossed target shareholders would commit an insider trading offence if they were to trade on the disclosed information about the impending takeover bid. ${ }^{131}$

Takeover bidders are also prohibited under the Market Abuse Regulation from engaging in warehousing target's shares. Bidder's chances of launching a successful takeover bid would be improved if the bidder tips other institutional investors about the planned takeover, who subsequently accumulate (i.e. warehouse) target's stock and in return for the tip, commit to sell their shares back to the bidder at an increased share price once the takeover bid is publicly announced. Obviously, warehousing benefits the bidder and the tippees, but is prohibited under the Market Abuse Regulation as it assumes behavior equal to unlawful tipping and insider trading. ${ }^{132}$ Instead, bidders and activists can acquire a maximum of $5 \%$ of the outstanding shares in a target firm, without having to make any public announcements under ownership disclosure rules. However, upon reaching the applicable ownership reporting threshold, which can be lower than $5 \%$ depending on the national transparency regulations of

129 Wong (fn. 76), 2359-2360. See generally Ryan Flugum/Choonsik Lee/Matthey E. Souther, "Shining a Light in a Dark Corner: EDGAR Search Activity Reveals the Strategically Leaked Plans of Activist Investors" (2020), <https://papers.ssrn.com/ sol3/papers.cfm?abstract_id=3612507> (conducting an empirical investigation of institutional investors' searches of U.S. firms on the SEC's EDGAR database in period of 10 days before an activist investors makes a 13D filing and finding a leak of information about an upcoming campaign from activist investors to unaffiliated institutional investors prior to $13 \mathrm{D}$ disclosures, and subsequent informed EDGAR searches by unaffiliated investors (i.e. downloads of target firm's financial and proxy statements) on the basis of such leaked information.

130 Art. 11(2) Regulation (EU) 596/2014.

131 Id., Art 5(b), (c).

132 Chiarella (fn. 23), 234 (explaining the practice of "warehousing”); Goshen/Parchomovsky (fn. 3), 1273-1276 (analyzing warehousing arrangements between bidders and other institutional investors from a market efficiency perspective). 
EU Member States ${ }^{133}$, investors should make a prompt disclosure to the issuer and to the securities regulator, and in any event no later than within 4 trading days ${ }^{134}$. Thus, wolf packs have a very limited opportunity to amass significantly more shares in the period between triggering the ownership disclosure threshold and complying with EU reporting requirements. ${ }^{135}$

Pre-disclosure share accumulations are important for both, bidders and activists. Holding higher initial toehold in the target is a strong signal that bidders will acquire a controlling interest in the target more quickly, whereas activists can approach management with more confidence that their demands will be met due to management's responsiveness or because their proposals will gain the required majority at contested general meetings or proxy contests. Yet, as was shown earlier, bidders can wall-cross major shareholders and in this manner secure their support beforehand. Wall-crossed shareholders have an incentive to consent to the market sounding because if the takeover bid is successful, they would soon be rewarded with a takeover premium. Also, major individual shareholders in the European context are usually long-term shareholders (individuals, families or other corporations) who can agree on being restricted from trading until the transaction goes public, as they do not have a preference for liquidity and making a quick exit at all times. Thus, even if they cannot "warehouse" shares with the help of other institutional investors, bidders can enlist the support of major shareholders prior to announcing the transaction.

133 See generally European Securities and Markets Authority, "Practical Guide: National Rules on Notification of Major Holdings under the Transparency Directive" (2019), $<$ https://www.esma.europa.eu/sites/default/files/library/practical_guide_major_ holdings_notifications_under_transparency_directive.pdf $>$ (last accessed 10 June 2020) (providing an overview of the beneficial ownership notification thresholds across EU Member States and the deadlines for complying with the respective notification obligation).

134 See Art. 12(2) Directive 2004/109/EC.

135 There has been a considerable debate in the U.S. on the desirability for shortening the ten-day window for blockholder disclosure under Section 13D of the Securities and Exchange Act of 1934 as a way of restricting activist investors from accumulating substantive amount of shares within the ten-day time leg; see generally Lucian A. Bebchuk/Robert J. Jackson Jr., "The Law and Economics of Blockholder Disclosure", Harvard Business Law Review 2 (2012), 39. For opposing views see Letter from Wachtell, Lipton, Rosen \& Katz to Elizabeth M. Murphy, Secretary, U.S. Securities and Exchange Commission, 7 March 2011, <https://www.sec.gov/rules/petitions/2011/ petn4-624.pdf $>$ (last accessed on 7 October 2019) (arguing that the rule should be amended to shorten the 10-day window to one business day and that investors are prevented from making further share acquisitions within two business days after filing Schedule 13D). 
Wolf-packs, on the other hand, are associations of actively managed funds who would ordinarily not agree to trading restrictions. Also, they would expect part of their "premium" for participating in the pack, if any, to come from pre-disclosure share acquisitions as arguably, they face more risk that the lead activist will succeed in its demands and as a result, they will be compensated by liquidating their position after a successful intervention. ${ }^{136}$ This is because activists are not always successful in their demands vis-à-vis management not only because of insufficient support from the shareholder base, but also because European corporate boards arguably have considerably more leeway to defend against activist measures, as opposed to fighting an ongoing takeover bid given the "board neutrality" rule under the EU Takeover Directive (implemented in the majority of national takeover laws of EU Member States). ${ }^{137}$

Lastly, one could argue that allowing pre-disclosure sharing and trading on inside information would be difficult to police and would lead to unrestricted insider trading by an (unknown) number of tipped investors that regulators would have difficult time to sanction. Under the Market Abuse Regulation, however, there is already a process in place to ensure diligent handling of inside information disclosed under the market-sounding rule that could also serve as a basis for unlawful leaks of inside information created by hedge fund activists. Namely, under the market-sounding provisions, the disclosing party should draft a written record regarding any inside information disclosed in the market sounding and that the receiving person consented to be wall-crossed and has undertaken to keep the information confidential. ${ }^{138}$ This written record also includes all disclosed information, the identity of the receiving party, date and time of disclosure and should be made available to regulators upon request. ${ }^{139}$ On this basis, regulators can determine with certainty whether any market participant violated the insider trading ban by entering into a specific securities

136 See also John C. Jr. Coffee/Robert J. Jr. Jackson/Joshua R. Mitts/Robert E. Bishop, "Activist Directors and Agency Costs: What Happens When an Activist Director Goes on the Board”, Cornell Law Review 104 (2019) 381 (providing empirical evidence that following the appointment of activist directors on target firm's boards there is an increase in informed trading in the firm's shares and arguing that such information leakages serve as a subsidy to hedge fund activism and keeps the wolf pack of activist investors together throughout the activist campaign).

137 See European Commission, "Report from the Commission to the European Parliament, The Council, The European Social and Economic Committee and the Committee of the Regions: Application of Directive 2004/25/EC on Takeover Bids" (2012) 3, $<$ https://eur-lex.europa.eu/legal-content/EN/TXT/PDF/?uri=CELEX:52012DC034 7\&from $=\mathrm{EN}>$ (last accessed 10 June 2020) (showing that 19 EU Member States have transposed the board neutrality rule of the EU Takeover Bids Directive).

138 Art. 11(3)-(5) Regulation (EU) 596/2014.

139 Id. 
transaction at a specific time. It also imposes a substantial book-keeping burden on disclosing parties, likely reducing their incentive to wall-cross a large number of investors.

\section{F. Conclusion}

The European policy on insider trading has been justifiably associated with the parity-of-information theory, given that the EU legislator has pronounced market integrity, investor confidence and equal access to information as the only objectives of EU insider trading rules. Yet, these laudable goals do not portray a full description of the interests protected under the EU Market Abuse Regulation.

In limited circumstances, EU insider trading rules allow market professionals that have developed and/or discovered socially valuable, material, non-public information to selectively share and/or trade on this information. These exceptions from informational parity contribute to the efficiency of European capital markets and doctrinally can be best explained under the property rights in information theory. For example, analysts can share with their clients (and trade on) the reports and recommendations they develop through diligent research. Actively managed funds can trade on the basis of their investment decisions and trading strategies. Companies may delay disclosure of proprietary information that would lose value if immediately made public and lastly, issuers of financial instruments and takeover bidders may selectively disclose their plans to selected investors in order to gauge their interest prior to publicly announcing the transaction.

The property rights-analysis of EU insider trading rules has significant doctrinal implications. It shows that the current fairness-based approach does not provide a comprehensive theoretical basis of the European insider trading regulatory framework and that there are important trade-offs between the parityof-information and the property rights in information theories embedded in the current EU insider trading rules.

Lastly, I analyze hedge fund activism through insider trading lens and show that activist campaigns would likely qualify as inside information under the EU Market Abuse Regulation. Consistent with the property rights approach, hedge funds in Europe can trade on their activist investment strategies but are restricted from tipping other institutional investors, as this would violate the EU tipping ban.

I argue, however, that allowing activists to share their strategies with fellow investors would be consistent with the property rights approach and that EU rules already give this right to information-owners in other contexts (e.g., mar- 
ket sounding). By extension, a property rights approach would also permit the tippees of activist investors to subsequently trade on the confidential information about the impending activist campaign, provided the information-owner (i.e. the activist) consents to such trading and the (inside) information is kept confidential. 